\title{
ANALISIS KOMODITI KELAPA SAWIT DAN DAMPAK EKONOMI TERHADAP KELANJUTAN KESEJAHTERAAN MASYARAKAT DI KABUPATEN LABUHANBATU
}

\author{
Zulkarnain Nasution \\ Staff Pengajar Fakultas Ekonomi Dan Bisnis Universitas Labuhanbatu \\ Zulkarnainnasution1974@gmail.co.id
}

\begin{abstract}
Abstrak
Penelitian yang dilakukan di Kabupaten Labuhanbatu ini memiliki tujuan yaitu Untuk menganalisis dampak keberadaan perkebunan sawit terhadap ekonomi dan kesejahteraan masyarakat. Jenis data yang digunakan dalam penelitian ini yaitu, data sekunder yang diperoleh dari BPS, Metode penelitian yang digunakan dalam penelitian ini adalah metode deskriptif, yaitu menggambarkan permasalahan yang ada di lapangan kemudian dianalisis sesuai fakta yang ada. Sedangkan alat analisis untuk menentukan dampak ekonom terhadap kesejateran di gunakan SPSS untuk menjawab hipotesis adanya perkebunan sawit.

Hasil analisis menunjukkan bahwa adanya perkebunan sawit kondisi sosial ekonomi masyarakat mengalami peningkatan karena dari data yang diperoleh dan diolah sehingga tingkat kesejateraan masyarakat semangkin meningkat. hasil uji kointegrasi menunjukkan bahwa terdapat dampak ekonomi dari peningkatan perkebunan kelapa sawit terhadap tingkat kesejateraan masyarakat dengan melihat data IPM kabupaten Labuhanbatu dengan melalui pertumbuhan ekonomi
\end{abstract}

Kata kunci : Perkebunan Sawit, kondisi ekonomi, kelanjutan kesejateraan

\section{PENDAHULUAN}

Dampak adalah suatu perubahan yang disebabkan oleh suatu kegiatan, suatu usaha di bidang investasi dalam kegiatan pembangunan memiliki kemampuan potensial menimbulkan dampak (dampak merupakan pengaruh yang mendatangkan akibat baik positif maupun negatif). Konsep dampak diartikan sebagai pengaruh munculnya aktifitas manusia dalam pembangunan terhadap lingkungan termasuk manusia.

Perkebunan kelapa sawit merupakan investasi jangka panjang yang dikelola secara profesional sehingga menguntungkan secara ekonomis terhadap perusahaan dan dapat meningkat kesejahteraan serta memberikan kontribusi terhadap peningkatan pendapatan masyarakat dilingkungan sekitar. Produksi minyak sawit indonesia baik CPO maupun PKO selain untuk memenuhi kebutuhan dalam negeri juga pasar ekspor. Peningkatan produksi membutuhkan peningkatan luas areal pertanaman untuk memenuhi peningkatan permintaan ekspor minyak dan inti sawit.

Kegiatan pengelolaan kelapa sawit merupakan salah satu jenis usaha yang potensial perencanaan yang baik karena merupakan investasi jangka panjang untuk mendapatkan produksi yang tinggi, budi daya kelapa sawit pemeliharaan yang intensif, baik ketika tanaman belum menghasilkan maupun tanaman sudah menghasilkan. (Hartanto: 2011).

Kegiatan investasi dalam bidang perkebunan pada dasarnya merupakan suatu kebutuhan. Kebutuhan bagi siapa saja, kebutuhan bagi perseorangan, institusi, korporasi maupun masyarakat luas pada umumnya. Indonesia merupakan salah satu negara yang 
memiliki kekayaan sumber daya alam yang tidak terbatas, tapi memiliki permasalahan dalam keterbatasan modal. Sehingga pemanfaatan investasi di bidang perkebunan menjadi solusi alternatif untuk meningkatkan secara progresif (boosting) nilai tambah sumber daya alam kita terhadap pasar global.

Sedangkan luas tanam kebun kelapa sawit rakyat di Sumatera Utara pada tahun 2018 sebesar 434,36 Ribu Ha dengan produksi 1682 ribu ton Tandan Buah Segar (TBS) kelapa sawit. Kabupaten Labuhan Batu merupakan salah satu kabupaten dengan yang memiliki luas perkebunan kelapa sawit di Sumatera Utara. Di daerah ini terdapat sebesar 35.1 ribu Ha kebun sawit atau 16,25 persen dari seluruh perkebunan kelapa sawit rakyat Sumatera Utara. Produksi kelapa sawit Kabupaten Labuhanbatu tahun 2018 adalah sebesar 125 775,01ton (Sumut Dalam Angka, 2019).

Dampak langsung ke petani kelapa sawit atas krisis ekonomi global ini mengakibatkan permintaan minyak sawit dunia menurun, sehingga industri minyak sawit di Indonesia harus dikurangi untuk mengimbangi supply atas permintaan minyak sawit yang menurun. Salah satu kegiatan ekonomi yang berperan dalam meningkatka pendapatan dan kesejahteraan masyarakat adalah perkebunan yang berbasis agribisnis. Selain menjadi fungsi pelestarian lingkungan hidup dan sebagai instrument pemerataan pembangunan rakyat. Potensi adanya pemanfaatan perkebunan yang dijadikan andalan ekspor dimasa mendatang sangatlah besar. Persyaratannya hanyalah perkebunan dan penyempurnaan iklim usaha serta struktur pasar komoditas perkebunan sektor hulu sampai hilir. Posisi Kabupaten Labuhanbatu sangatlah strategis untuk membudidayakan tanaman kelapa sawit, adanya perkebunan yang sudah luas diharapkan mampu mengubah kehidupan masyarakat Labuhanbatu dan sekitarya lebih baik lagi. Tidak dapat dipungkuri lagi bahwa perkebunan kelapa sawit telah menjadi sektor yang sangat penting peranannya dalam pembangunan, karena sektor ini adalah penyumbang devisa yang cukup besar di Indonesia.

Prospek kelapa sawit yang dari waktu kewaktu akan terus bertumbuh yang diiringi dengan tingkat produksi dan luas areal yang kian bertambah di tiap tahunnya. Namun hal terebut belum tentu menjadi jaminan terhadap peningkatan kesejahteraan dan kemajuan daerah. Oleh karena itu penulis ingin mengetahui tentang bagaimana peran dari sektor perkebunan kelapa sawit dalam memajukan wilayah di Kabupaten Labuhanbatu karena melihat Kabupaten Labuhanbatu memiliki perkebunan kelapa sawit luas di Sumatera Utara.

Salah satu prasyarat yang harus dipenuhi adalah meningkatkan pertumbuhan ekonomi. Peningkatan tersebut harus didukung dengan kemampuan tabungan yang memadai agar dapat melaksanakan pembangunan demi peningkatan kesejahteraan masyarakat serta partisipasi peningkatan pendidikan dalam. Pertumbuhan ekonomi Kabupaten Labuhanbatu yang berdampak pada peningkatan kesejahteraan masyarakat, tidak dapat diraih apabila tidak didukung dengan kemampuan atau daya saing dari sebuah negara

\section{Peranan dan Ekonomi Perkebunan Kelapa Sawit}

Sektor perkebunan memiliki peranan yang sangat potensial di dalam dan diluar negeri. Di dalam negeri produk sektor perkebunan dapat dikonsumsi langsung oleh masyarakat dan sebagai bahan baku industri. Bila diusahakan secara sungguh-sungguh atau profesional bisa menjadi suatu bisnis yang menjadikan keuntungan besar. Kehadiran perkebunan kelapa sawit memang membuka peluang yang besar dalam mengatasi pengangguran, karena faktanya jutaan orang menggantungkan hidup mereka dalam sektor perkebunan ini, bahkan kelapa sawit juga merupakan salah satu tanaman multiguna yang mulai menggantikan posisi penanaman pada 
komoditas perkebunan lain, yaitu tanaman karet. Hal ini membuat kelapa sawit menjadi salah satu komoditas unggulan dan banyak dibudidayakan (Perdamean, 2016)

Kelapa Sawit telah menjadi salah satu komoditas unggulan perkebunan, dan pengembangannya akan terus diupayakan sejalan dengan perkembangan atau pertumbuhan permintaan, baik untuk pemenuhan kebutuhan dalam negeri maupun untuk ekspor. Tingginya konsumsi domestik dan besarnya permintaan untuk ekspor merupakan salah satu faktor yang mempengaruhi peningkatan produktivitas kelapa sawit. Komoditas kelapa sawit yang memiliki berbagai macam kegunaan baik untuk industri pangan maupun non pangan, juga memiliki prospek pengembangannya yang tidak saja terkait dengan pertumbuhan permintaan minyak nabati dalam negeri namun juga di dunia

\section{Teori Pembangunan Perkebunan Sawit}

Pembangunan perkebunan khususnya kelapa sawit di Indonesia telah membawa dampak ekonomi terhadap masyarakat, baik masyarakat yang terlibat dengan aktivitas perkebunan maupun terhadap masyarakat sekitarnya. Dari hasil penelitian Almasdi Syahza (2007) menjelaskan bahwa pembangunan perkebunan kelapa sawit dapat mengurangi ketimpangan pendapatan antar golongan masyarakat dan mengurangi ketimpangan ekonomi antar kabupaten/kota; menciptakan multiplier effect ekonomi dan meningkatkan kesejahteraan masyarakat pedesaan; dan ekspor produk turunan kelapa sawit (CPO) dapat merangsang pertumbuhan ekonomi daerah. Tingkat kesejahteraan yang dirasakan oleh masyarakat pedesaan telah membawa dampak berkembangnya perkebunan di daerah, khususnya kelapa sawit.

Menurut Undang-Undang tentang perkebunan yaitu UU No 18 Tahun 2004, perkebunan adalah segala kegiatan yang mengusahakan tanaman tertentu pada tanah dan/atau media tumbuh lainnya dalam ekosistem yang sesuai, mengolah dan memasarkan barang dan jasa hasil tanaman tersebut, dengan bantuan ilmu pengetahuan dan teknologi, permodalan serta manajemen untuk mewujudkan kesejahteraan bagi pelaku usaha perkebunan dan masyarakat. Penegrtian ini menunjukan bahwa perkebunan merupakan kegiatan usaha baik dilakukan oleh rakyat maupun oleh perusahan atau lembaga berbadan hukum. Dengan pengertian ini maka perkebunan tidak menunjuk atau membatasi pada komoditas tertentu, melainkan semua komoditas tanaman, yang hasilnya diolah dan diperuntukan terutama bukan bagi pasar lokal, melainkan pasar nasional sampai pasar global.

\section{Teori Faktor Ekonomi}

Menurut Ishomuddin (1992), dalam kehidupannya, manusia harus memenuhi kebutuhan materialnya untuk melangsungkan hidupnya, hal tersebut dapat diwujudkan melalui pranata-pranata mereka dengan memanfaatkan sumber daya alam, modal dan tenaga kerja yang terbatas. Studi mengenai hal tersebut disebut ilmu ekonomi. Salah satu faktor yang berpengaruh dalam ekonomi masyarakat adalah tingkat pendapatan masyarakat.

Menurut Nurmanaf (1988) secara sederhana dikatakan bahwa pendapatan rumah tangga dapat berasal dari satu atau lebih macam sumber pendapatan. Sumber pendapatan tersebut ada yang berasal dari sektor perkebunan maupun dari luar sektor perkebunan yang dapat diperinci lebih lanjut kedalam berbagai subsektor dan masing-masing subsektor memberikan kontribusi yang berbeda-beda terhadap total pendapatan rumah tangga. Hal ini akan menciptakan perbedaan pada struktur pendapatan rumah tangga.

\section{Teori Kesejahteraan Masyarakat}

Menurut Whithaker dan Federico (1997), pengertian kesejahteraan sosial merupakan sistem suatu bangsa tentang manfaat dan jasa untuk membantu masyarakat guna memperoleh 
kebutuhan sosial, ekonomi, pendidikan, kesehatan yang penting bagi kelangsungan masyarakat tersebut. Seseorang yang mempunyai kekurangan kemampuan mungkin memiliki kesejahteraan yang rendah,kurangnya kemampuan dapat berarti kurang mampu untuk mencapai fungsi tertentu sehingga kurang sejahtera. Terdapat beragam pengertian mengenai kesejahteraan, karena lebih bersifat subjektif dimana setiap orang dengan pedoman, tujuan dan cara hidupnya yang berbeda-beda akan memberikan nilai-nilai yang berbeda pula tentang kesejahteraan dan faktor-faktor yang menentukan tingkat kesejahteraan (Rukminto, 2013).

Sedang menurut Rambe (2004), kesejahteraan adalah suatu tata kehidupan dan penghidupan sosial, material, maupun spiritual yang diliputi rasa keselamatan, kesusilaan dan ketentraman lahir batin yang memungkinkan setiap warganegara untuk mengadakan usahausaha pemenuhan kebutuhan jasmani, rohani dan sosial yang sebaik-baiknya bagi diri, rumah tangga serta masyarakat. Berdasarkan tingkat ketergantungan dari dimensi standar hidup (standard of living) masyarakat, maka tingkat kesejahteraan masyarakat dapat dibedakan kedalam satu sistem kesejahteraan (well-being) dan dua subsistem, yakni: 1) subsistem sosial; dan 2) subsistem ekonomi, dengan beberapa faktor di antaranya kesejahteraan manusia, kesejahteraan sosial, konsumsi, tingkat kemiskinan, dan aktivitas ekonomi (World Bank: Santamarina etal., 2004).

\section{METODE PENELITIAN}

Penelitian yang dilakukan dengan penelitian deskriptif yaitu menggambarkan masalah-masalah yang berhubungan dengan tujuan penelitian seperti apa adanya, dengan mengumpulkan data dan menjelaskan data yang diperoleh sesuai dengan keperluan.

\section{Jenis Data dan Sumber Data}

Data diperoleh dari satu sumber yaitu sumber data sekunder yang diperoleh melalui laporan dari instansi terkait yaitu kantor BPS Kabupaten Labuhanbatu, data time series selama tahun 2010 sampai dengan 2018., masyarakat dan pihak pengambil kebijakan yaitu pemerintah daerah serta instansi vertikal.

\section{Analisis Data}

Atas dasar landasan teoritis dan empiris tersebut maka peneliti mencoba untuk melakukan studi yang berhubungan dengan kebijakan Pemerintah Daerah Kabuapeten Labuhanbatu yang dalam dasawarsa ini telah melakukan perluasan perkebunan sawit, serta bagaimana dampaknya ekonomi terhadap kesejahteraan masyarakat.

Untuk memenuhi tujuan penelitian yang telah ditetapkan maka dilakukan dengan analisis deskripsi tentang perkembangan komoditi perkebunan sawit, dampak kebijakan dan dampak kegiatan komoditi perkebunan sawit di daerah Kabupaten Labuhanbatu. Dari analisis tersebut diharapkan dapat memperoleh gambaran mengenai konsistensi serta kesinambungan kebijakan komoditi perkebunan sawit sebagai salah satu instrumen kebijakan pemerintah daerah dari tahun ke tahun.

\section{HASIL DAN PEMBAHASAN \\ Perkembangan Perkebunan Kelapa Sawit}

Perkembangan perkebunan kelapa sawit di Kabupaten Labuhanbatu memberikan peran penting dalam kesejahteraan masyarakatnya dan kemajuan daerah, dilihat dari profibilitas kelapa sawit yang tinggi. Adanya peningkatan luas lahan dari tahun ke tahun yang artinya mulai banyak pihak yang berinvestasi pada perkebunan kelapa sawit, baik dari perkebunan swasta ataupun perkebunan rakyat yang keduanya sama-sama memiliki peran penting disektor pertanian 
Kabupaten Labuhanbatu. Dapat dilihat dari kontribusi pertaniannya terhadap Produk Domestik Regional Bruto (PDRB) yang cukup fluktuatif besar dari tahun ke tahun

Tabel 1 Perkembangan Luas Serta Produksi Perkebunan Kelapa Sawit Kabupaten Labuhanbatu tahun 2010-2019

\begin{tabular}{|c|c|c|r|}
\hline Tahun & Luas Area & Pertumbuahn & Produksi \\
\hline 2010 & 33347 & - & $443.475,00$ \\
\hline 2011 & 33546 & 0,593215 & $439.159,00$ \\
\hline 2012 & 36715 & 8,63135 & $348.647,36$ \\
\hline 2013 & 34559 & $-6,23861$ & $581.159,09$ \\
\hline 2014 & 34712 & 0,44077 & $423.625,00$ \\
\hline 2015 & 34648 & $-0,18471$ & $474.600,00$ \\
\hline 2016 & 34795 & 0,422474 & 536.909 .09 \\
\hline 2017 & 34339 & $-1,32794$ & 540.856 .54 \\
\hline 2018 & 35160 & 2,33504 & 425.775 .01 \\
\hline
\end{tabular}

Dari tabel diatas menunjukkan bahwa produksi CPO (Crude Palm Oil) pada perkebunan kelapa sawit di Labuhanbatu tahun 2010 sampai dengan tahun 2018 produksi CPO mengalami penurunan dan mengalami peningkatan dari tahun sebelumnya. Sebagai komoditi perkebunan yang penting bagi Kabupaten Labuhanbatu diharapkan produksi kelapa sawit terus meningkat setiap tahunnya. Ada beberapa faktor yang sangat mempengaruhi pertumbuhan dan produksi kelapa sawit, diantaranya adalah luas areal perkebunan kelapa sawit, tenaga kerja dan harga CPO. Menurut Pusat Data dan Informasi Pertanian Kementerian Pertanian (2010:7), seiring dengan peningkatan luas areal kelapa sawit pada tahun 2018, maka produksi kelapa sawit Kabupaten Labuhanbatu dalam wujud produksi minyak sawit belum mengalami peningkatan di sebabkan perluasan kebun sawit belum menghasilkan buah tanda sawit yang bisa di panen.

\section{Serapan Tenaga Kerja}

Dalam bidang perkebunan, tenaga kerja merupakan faktor produksi kedua setelah lahan. Penggunaan tenaga kerja dinyatakan dalam besaran curahan hari kerja, yaitu curahan hari kerja dari tenaga kerja efektif yang terpakai. Sumber tenaga kerja berasal dari dalam keluarga dan luar keluarga. Kebutuhan tenaga kerja pada kegiatan produksi tanaman perkebunan sangat bervariasi. Tenaga kerja yang terserap adalah tenaga kerja keluarga. Hal ini didukung oleh Kadir dan Syapsan (2012) yang menyatakan bahwa sebagain besar tenaga kerja perkebunan rakyat menggunakan tenaga kerja keluarga. Beberapa kegiatan yang dilakukan dan membutuhkan tenaga kerja diantaranya adalah pengolahan lahan, penanaman, pemupukan, pengendalian gulma, hama dan penyakit, dan panen. Jumlah hari orang kerja (HOK) untuk komoditi kelapa sawit.

Tabel 2 . Besaran Pentyerapan Tenaga Kerja Di Sub Sektor Perkebunan Kelapa Sawit

\begin{tabular}{|c|c|c|c|}
\hline Tahun & $\begin{array}{c}\text { Pertumbuhan } \\
\text { Tenaga Kerja }\end{array}$ & $\begin{array}{c}\text { Pertumbuhan } \\
\text { Produksi Kelapa } \\
\text { Sawit }\end{array}$ & Elastisitas \\
\hline $\mathbf{2 0 1 0}$ & - & - & - \\
\hline $\mathbf{2 0 1 1}$ & 5,44238 & $-0,97322$ & $-5,59214$ \\
\hline $\mathbf{2 0 1 2}$ & 4,798107 & $-20,6102$ & $-0,2328$ \\
\hline $\mathbf{2 0 1 3}$ & $-3,18552$ & 66,68966 & $-0,04777$ \\
\hline $\mathbf{2 0 1 4}$ & $-8,83992$ & $-27,1069$ & 0,326113 \\
\hline $\mathbf{2 0 1 5}$ & $-1,24993$ & 12,03305 & $-0,10387$ \\
\hline
\end{tabular}


JURNAL ECOBISMA VOL 2 NO. 1 JAN 2015

\begin{tabular}{|l|l|l|l|}
\hline $\mathbf{2 0 1 6}$ & $-1,76907$ & 13,12876 & $-0,13475$ \\
\hline $\mathbf{2 0 1 7}$ & $-5,54168$ & 0,735218 & $-7,53747$ \\
\hline $\mathbf{2 0 1 8}$ & $-7,97726$ & $-21,2776$ & 0,374914 \\
\hline
\end{tabular}

Dari tabel di atas menunjukkan bahwa pertumbuhan tenga kerja disektor perkebunan mengalami penurunan sehingga dari tahun 2011 sebesar 5,44\% dan mengalami penurunan di tahun 2012 menjadi sebesar 4,798 \%. Dan dari tahun ke tahun mengalami penurunan hingga negatif ini mengartikan bhawa sektor pertanian khususnya sub sektor perkebunan di kabupaten Labuhanbatu tidak mengalami permintaan terhadap tenaga kerja sehingga masyarakat sekitar perkebunan sawit mengalami peningkatan jumlah penggaguran dan akan berdampak pada sektor perekonomian Kabupaten Labuhanbatu.

Pada tabel pertumbuhan produksi kelapa sawit juga terjadi fluaktuasi dari tahun 2010 sampai dengan tahun 2018 ini . hasil produksi akan menandakan jumlah pendapatan perkapitan dan jumlah pendapatan asli daerah. Pertumbuhan produksi kelapa sawit yang mengalami penurunan terjadi di tahun 2011, 2014, dan tahun 2018, sehingga pada tahun tersebut pencapaian target pajak dari sub sektor perkebunan tidak tercapai target yang sudah tercatat.

Pada tabel elastisitas berkategori inelastis dengan angka negatif di tunjukkan pada tahun 2012, 2013, 2015, 2016 dan tahun 2017, menunjukkan bahwa tidak terjadi pertumbuhan penyerapan tenaga kerja justru terjadi pengurangan jumlah tenaga kerja dibanding tahun sebelumnya. Persentase pengurangan tenaga kerja yang terjadi lebih kecil dari persentase pertumbuhan ekonomi yang tercipta. Kondisi ini tidak baik bagi perekonomian karena pengurangan tenaga kerja dapat berarti peningkatan angka pengangguran. Hal ini biasanya terjadi karena pertumbuhan ekonomi yang melambat sehingga kurang bergairahnya sektor-sektor usaha lalu terdapat perusahaan-perusahaan yang melakukan efisiensi dengan mengurangi tenaga kerjanya.

Tabel 3 Tingkat Kesejahteraan Masyarakat

\begin{tabular}{|c|c|c|c|c|c|}
\hline Tahun & $\begin{array}{c}\text { Jumlah } \\
\text { Penduduk } \\
\text { Miskin }\end{array}$ & $\begin{array}{c}\text { Kesejahteraan } \\
\text { Masyarakat }\end{array}$ & $\begin{array}{c}\text { PDRB } \\
\text { Perkapita }\end{array}$ & $\begin{array}{c}\text { Tingkat } \\
\text { Pengangguran } \\
\text { Terbuka }\end{array}$ & IPM \\
\hline 2010 & 47405 & 30681 & 18333913,00 & 7,04 & 66.88 \\
\hline 2011 & 42610 & 33299 & 20406918,00 & 5,88 & 67.88 \\
\hline 2012 & 42010 & 33119 & 37390288,20 & 7,80 & 68.64 \\
\hline 2013 & 38010 & 29607 & 38817561,85 & 8,93 & 69.45 \\
\hline 2014 & 37350 & 28580 & 40043871,74 & 7,72 & 70.06 \\
\hline 2015 & 42630 & 27220 & 41283786,88 & 11,39 & 70.23 \\
\hline 2016 & 41940 & 25223 & 42604783,14 & 10,56 & 70.5 \\
\hline 2017 & 29431 & 22647 & 60658159,21 & 7,09 & 71.00 \\
\hline 2018 & 33956 & 23543 & 45453757,11 & 6,98 & 71.39 \\
\hline
\end{tabular}

Kondisi sosial ekonomi di Kabupaten Labuhanbatu pada umumnya dan di sektor pertanian pada khususnya. Oleh sebab itu, fenomena kemiskinan di Kabupaten Labuhanbatu tidak dapat dipahami sepenuhnya tanpa memahami fenomena kemiskinan di perdesaan atau di sektor pertanian khususnya perkebunan. Pernyataan ini didukung oleh banyak fakta. Fakta pertama adalah bahwa sektor terbesar dalam menyerap tenaga kerja di kabupaten labuhanbatu selama ini adalah pertanian. Berdaasrkan data diatas bahwa Kabupaten Labuhanbatu memiliki jumlah penduduk yang sebagian besar berada di desa dan bermata pencarian sektor pertanian di sub sektor perkebunan. Karena tingkat ketergantungan begitu tinggi terhadap sektor perkebunan 
mengakibatkan jumlah penduduk begutu sulit memperoleh mata pencaharian dan sebagian masyrakat jumlah data kemiskinan di Kabupaten Labuhanbatu semakin meningkat di tahun 2018.

Sebagaimana pencapaian kesejahteraan masyarakat secara individual dengan ukuran materiil. Bagaimana ketenteraman, pemahaman keyakinan hidup, keramahan dan sikap tidak menggerutu dalam kehidupan adalah menjadi bagian perasaan yang terdalam dalam hidup sejahtera. Indikator kesejateraan masyarakat cara hidup masyarakat tradisional di desa, dimana tidak ditandai oleh gaya hidup kelimpahan materiil dan sangat sederhana. Komunitas memegang peranan penting bahwa kesejahteraan seseorang sangat ditentukan oleh bagaimana pemerintah mengelola daerah menjamin kesejahteraan para anggota masyarakat. Pada saat ini di perkebunan-perkebunan selalu memiliki institusi resolusi konflik. Harmoni menjadi bagian yang didambakan untuk memahami kesejahteraan. Saling menjamin antar tetangga jika terjadi kesulitan. Konsep Patron-Klien (pattern client relationships) dalam konseptualisasi pikiran materiil dan individualis adalah sebuah bentuk eksploitasi dari patron ke klien, namun pemerintah seperti ini adalah hubungan yang saling menjamin antara pemilik tanah luas dan tak bertanah (landless). James C. Scott (1976:41).

Sektor pertanian khusus perkebunan sawit dapat meningkatkan proses pembangunan ekonomi atau industrialisasi, pertumbuhan penduduk dan peningkatan pendapatan masyarakat rata-rata per kapita. Namun demikian, sesuai sistem perekonomian kebupaten Labuhanbatu yang mengedepankan keadilan sosial demi mencapai kesejahteraan masyarakat, pemerintah harus tetap berusaha, di satu sisi, tingkat pendapatan masyarakat di Kabupaten Labuhanbatu sebagian penduduk melakukan alih fungsi lahan pertanian, terutama mencegah pemusatan kepemilikan tanah oleh keluarga-keluarga kaya atau pemodal-pemodal besar yang hidup di perkotaan untuk tujuan-tujuan non-produktif atau yang tidak menciptakan sumber pendapatan atau kesempatan kerja yang signifikan bagi masyarakat, dan, di sisi lain, mempermudah petani mendapatkan sertifikat tanah. Jika penguasaan tanah oleh segelintir orang terus dibiarkan, sementara petani, khususnya dari kelompok skala kecil.

Pada tahun 2008 nilai pendapatan perkapita mengalami penurunan di akibatkan nilai tukar komiditi sektor perkebunan mengalami penurunan. Penurunan nilai tukar petani sektor perkebunan sawit di akibatkan oleh harga CPO di pasaran internasional mengalami penurunan sehingga berdampak pada petani di Indonesia pada umumnya dan secara khusus juga bagi petani sawit yang ada di Kabupaten Labuhanbatu.

Indeks Pembangunan Manusia (IPM) mengukur capaian pembangunan manusia berbasis sejumlah komponen dasar kualitas hidup. Sebagai ukuran kualitas hidup, IPM dibangun melalui pendekatan tiga dimensi dasar. Dimensi tersebut mencakup umur panjang dan sehat; pengetahuan, dan kehidupan yang layak. Ketiga dimensi tersebut memiliki pengertian sangat luas karena terkait banyak faktor. Untuk mengukur dimensi kesehatan, digunakan angka harapan hidup waktu lahir. Selanjutnya untuk mengukur dimensi pengetahuan digunakan gabungan indikator angka melek huruf dan rata-rata lama sekolah. Adapun untuk mengukur dimensi hidup layak digunakan indikator kemampuan daya beli masyarakat terhadap sejumlah kebutuhan pokok yang dilihat dari rata-rata besarnya pengeluaran per kapita sebagai pendekatan pendapatan yang mewakili capaian pembangunan untuk hidup layak.

\section{Kondisi Indikator Ekonomi Kabupaten Labuhanbatu}

Hal ini dibuktikan dengan setelah adanya perusahaan banyak sarana sosial publik yang dulunya tidak ada sekarang menjadi ada, seperti Jalan raya, dengan adanya jalan raya maka penduduk lebih mujdah untuk bersosialisasi terhadap penduduk yang lain terutama dengan 
jarak yang jauh. Selain itu ada juga Rambu-rambu jalan, dengan adanya rambu-rambu jalan akan mengurangi terjadinya kecelakaan karena pengguna jalan lebih patuh pada rambu-rambu tersebut dan menjadikannya sebagai patokan berkenderaan. Ada juga saluran air,denganadanya saluran air maka kebutuhan penduduk lebih terjamin karena penduduk membutuhkan air untuk melangsungkan hidupnya. Selanjutnya dibangunkan juga jembatan, dengan begitu lebih mudah penduduk untuk berhubungan dengan penduduk di desa seberang. Didirikan juga puskesmas, membuat masyarakat bisa memeriksakan kesehatannya lebih cepat dan dapat mendapatkan penanganan terlebih dahulu sebelum di rujuk ke Rumah Sakit jika penyakitnya parah begitu juga dengan didirikannya posyandu,berarti penduduk bisa mendapatkan imunisasi lengkap dengan rutinnya menghadiri posyandu setiap bulannya.

\section{Tabel 4 Indikator Ekonomi}

\begin{tabular}{|c|l|c|c|c|c|c|c|c|c|c|}
\hline No & \multicolumn{1}{|c|}{ Sektor } & $\mathbf{2 0 1 0}$ & $\mathbf{2 0 1 1}$ & $\mathbf{2 0 1 2}$ & $\mathbf{2 0 1 3}$ & $\mathbf{2 0 1 4}$ & $\mathbf{2 0 1 5}$ & $\mathbf{2 0 1 6}$ & $\mathbf{2 0 1 7}$ & $\mathbf{2 0 1 8}$ \\
\hline 1 & Pendapatan Perkapita & & & & & & & & & \\
\hline & a. Tingkat pengeluaran (Dalam Ribuan) & 9762 & 9909 & 10058 & 10210 & 11250 & 11535 & 11687 & 11846 & 11.053 \\
\hline & b. Ketersediaan Lapangan Kerja ( Jiwa ) & 560 & 249 & 221 & 86 & 59 & 28 & 13 & 182 & 64 \\
\hline & c. Tingkat Partisipasi Angkatan Kerja (\%) & 59,93 & 73,55 & 59,48 & 66,7 & 63,22 & 59,95 & 57,78 & 56,15 & 67,94 \\
\hline 2 & Tingkat Pendapatan & & & & & & & & & \\
\hline & a. Pendapatan Perbulan (Dalam Ribuan ) & 477.755 & 606,72 & 633,57 & 658,18 & 724,69 & 749,69 & 860,54 & 781,32 & $1.057,81$ \\
\hline
\end{tabular}

Dari tabel di atas, Gambaran tersebut menunjukkan bahwa PDRB per kapita kabupaten Labuhabatu melalui tingkat pengeluaran telah meningkat cukup tajam selama lima tahun terakhir sebagaimana terlihat pada tabel diatas, kendati telah melemah selama dua tahun terakhir karena perlambatan ekonomi. Meskipun demikian tetap harus dipertanyakan apakah PDRB perkapita adalah alat ukur yang layak untuk kabupaten Labuhanbatu karena penduduk kabupaten Labuhanbatu memiliki karekteristik ketidaksetaraan yang cukup tinggi dalam distribusi pendapatan. Mencapai level PDRB per kapita sebesar 11 juta bisa saja dianggap sebagai langkah yang penting sebab hal ini seharusnya dapat menyebabkan percepatan pengembangan di sejumlah sektor (seperti retail, otomotif, properti) karena permintaan konsumen yang meningkat dan karenanya menjadi katalis pertumbuhan ekonomi.

Ketersediaan lapangan kerja yang rendah merupakan penyebab lain dari meningkatnya angka pengangguran, permintaan pasar kerja masih didominasi oleh sektor pertanian, industri, perdagangan,dan jasa. Sektor lainnya menjadi andalan utama karena daya serapnya yang tinggi disebabkan karena persyaratan angkatan kerja yang dibutuhkan tidak terlalu tinggi secara kualitas, sementara itu sektor-sektor lainnya masih belum mampu memberikan kontribusi yang luas pada kesempatan kerja bagi para tenaga kerja yang cenderung meningkat jumlahnya.

Dari tabel di atas dapat dilihat bahwa dari tahun 2010-2018 Tingkat Partisipasi Angkatan Kerja di Kabupaten Labuhanbatu mengalami kenaikan dan penurunan. Tingkat Partisipasi Angkatan Kerja (TPAK) tergantung pada kategori orientasi investasi. Industri padat karya atau industri padat modal inilah yang juga bisa berkaitan dengan preferensi masingmasing investor tentang kondisi iklim ekonomi yang terjadi sebagai bahan pertimbangan. Pada kondisi padat karya lebih banyak menggunakan tenaga kerja manusia jika dibandingkan dengan tenaga mesin pendekatan tersebut merupakan pendekatan yang bersifat untuk 
mengkreasikan pengembangan diri melalui penyerapan tenaga kerja diharapkan akan timbul suatu jumlah produktivitas yang bertahap nantinya. Dalam padat modal jelas menginginkan produktivitas yang bergerak cepat, efisiensi biaya pada faktor input, pengandalan teknologi tinggi dan kemutakhiran. Menjadikan kualifikasi tenaga kerja yang begitu tinggi yang akan berdampak penyerapan tenaga kerja yang cenderung sedikit karena pemanfaatan teknologi tinggi yang menuntut keahlian dan spesialisasi bagi tenaga kerja yang lain dalam mengoperasikan sebuah alat teknologi tersebut.

Rumah tangga merupakan konsumen atau pemakai barang dan jasa sekaligus juga pemilik faktor-faktor produksi tenaga kerja, lahan, modal dan kewirausahaan. Rumah tangga menjual atau mengelola faktor-faktor produksi tersebut untuk memperoleh balas jasa. Balas jasa atau imbalan tersebut adalah upah, sewa, bunga dividen, dan laba yang merupakan komponen penerimaan atau pendapatan rumah tangga.

Penerimaan lain yang mungkin diperoleh rumah tangga adalah transfer (pemberian cuma-cuma), perkiraan pendapatan (imputasi) dari rumah milik rumah tangga tersebut yang ditempati sendiri atau ditempati pihak lain dengan bebas sewa, dan hasil produksi barang/jasa dari kegiatan yang tidak digolongkan sebagai kegiatan usaha rumah tangga. Transfer yang diterima berasal dari pemerintah, badan usaha, lembaga nirlaba, rumah tangga lain, maupun dari luar negeri.

Ada dua cara penggunaan pendapatan. Pertama, membelanjakannya untuk barangbarang konsumsi. Kedua, tidak membelanjakannya seperti ditabung. Pengeluaran konsumsi dilakukan untuk mempertahankan taraf hidup. Pada tingkat pendapatan yang rendah, pengeluaran konsumsi umumnya dibelanjakan untuk kebutuhan-kebutuhan pokok guna memenuhi kebutuhan jasmani. Konsumsi makanan merupakan faktor terpenting karena makanan merupakan jenis barang utama untuk mempertahankan kelangsungan hidup. Akan tetapi terdapat berbagai macam barang konsumsi (termasuk sandang, perumahan, bahan bakar, dan sebagainya) yang dapat dianggap sebagai kebutuhan untuk menyelenggarakan rumah tangga. Keanekaragamannya tergantung pada tingkat pendapatan rumah tangga. Tingkat pendapatan yang berbeda-beda mengakibatkan perbedaan taraf konsumsi.

Apabila penerimaan rumah tangga dikurangi dengan pengeluaran untuk konsumsi dan untuk transfer, maka diperoleh nilai tabungan rumah tangga. Kalau perilaku konsumsi memperlihatkan dasar pendapatan yang dibelanjakan, maka tabungan adalah merupakan unsur penting dalam proses pertumbuhan dan pembangunan ekonomi. Tabungan memungkinkan terciptanya modal yang dapat memperbesar kapasitas produksi perekonomian. Untuk dapat melihat apa yang dilakukan rumah tangga responden atas tabungannya dibutuhkan data tabungan seperti yang disimpan di bank atau koperasi, jumlah investasi, serta transaksi keuangan lainnya.

Kenyataannya, selisih penerimaan dengan pengeluaran rumah tangga responden ada yang negatif (defisit), sehingga dalam membiayai pengeluaran dan investasinya diperlukan pinjaman (hutang), maka rumah tanggapun ada yang berhutang, dan ada yang meminjamkan uang (piutang). Jadi selain dari tabungan, sumber dana investasi dapat berasal dari pinjaman. Disamping itu, ada pula rumah tangga responden yang melakukan kegiatan di pasar uang atau di pasar modal sehingga terjadi transaksi finansial (keuangan) antar rumah tangga maupun dengan sektor ekonomi lain. Investasi finansial dapat berupa uang tunai, simpanan di bank, dan pemilikan surat berharga. 
Rumah tangga terdiri dari sekelompok orang yang mempunyai karakteristik berbeda, baik dalam hal penerimaan maupun pengeluarannya. Dalam hal pengeluaran konsumsi ada yang dilakukan secara bersama, tetapi ada pula yang dilakukan oleh masing-masing art. Sedangkan dalam hal pendapatan, ada rumah tangga responden yang pendapatannya dari upah/gaji saja, dari usaha saja, atau dari gabungan keduanya. Bahkan ada yang dari selain keduanya, misalnya dari pensiun, bagi hasil, dan sebagainya. Hal ini tergantung dari keaktifan krt/art dalam kegiatan ekonomi. Sehubungan dengan hal-hal yang disebutkan tadi, maka untuk mengukur penerimaan dan pengeluaran rumah tangga responden secara lengkap perlu diperhatikan bahwa:

a. Selain data komponen pengeluaran bersama di rumah tangga, juga harus ikut dicatat pengeluaran masing-masing art.

b. Selain data pendapatan dari usaha bersama, juga harus ikut dicatat penerimaan masingmasing art yang telah berpenghasilan

Model estimasi yang digunakan dalam penelitian ini adalah regresi linier berganda sederhana. Berdasarkan hasil analisis yang dilakukan, maka dirumuskan model estimasi tingkat kesejahteraan masyarakat dengan mengunakan Pertumbuhan Ekonomi Kabupaten Labuhanbatu sebagai berikut :

$$
\begin{aligned}
\mathrm{PE}= & 13.303-.0,931 \mathrm{~K}-0.339 \text { Pra. } \mathrm{S}+0.870 \text { PDRB. } \mathrm{K}+0,384 \mathrm{PDRB} \mathrm{IP}+0, .027 \mathrm{LHL}- \\
& \text { 1.551 LHR - 0,044 L. } . \text { Saw }
\end{aligned}
$$

Sebelum dilakukan uji selanjutnya, ada baiknya dilakukan dulu pengujian masalah dalam regresi linier klasik.

\section{Pengujian Masalah dalam Regresi Linear Klasik}

\section{Masalah Multikollinearitas}

Masalah mulitikolinearitas adalah situasi dimana adanya korelasi antara variabel bebas dengan variabel bebas lainnya. Dengan kata lain, dapat dikatakan bahwa sebuah model persamaan dinyatakan terdapat gangguan multikolinier apabila $\mathrm{R}^{2}$-nya tinggi namun hanya sedikit atau bahkan tidak ada variabel bebasnya yang tidak signifikan pada pengujian t-statistik.

Salah satu cara untuk mengetahui variabel bebas lainnya adalah dengan melakukan regresi atas satu variabel bebas terhadap variabel bebas lainnya, dan menghitung nilai $\mathrm{R}^{2}$ nya. Apabila nilai $\mathrm{R}^{2}$ hasil regresi tersebut lebih kecil dari nilai $\mathrm{R}^{2}$ hasil perhitungan regresi output terhadap variabel input secara keseluruhan maka tidak terdapat masalah mulitikolinear. Selain itu, multikolinieritas juga dapat dilihat melalui matriks korelasi antar variabelnya. Menurut Gujarati, multikolinieritas terjadi jika korelasi antar variabelnya lebih besar dari 0,80 .

Dari hasil matriks korelasi diatas dapat diambil kesimpulan bahwa telah terjadi multikolinieritas antar variable bebas, yaitu variable K (Kemiskinan ), Pra s (Keluarga Prasejahtera ), PDRB Perkebunan Sawit (PDRB KS), PDRB Industri Pengelolaan (PDRB IP), Hutan Lindung (Hut L), Hutan Rakyat (Hut R), Luas Sawah (L.Saw)

Perhatikan nilai VIF dan Tolerance. Kedua ini adalah indikasi kuat yang sering dipakai oleh para peneliti untuk menyimpulkan fenomena terjadinya interkorelasi variabel 
bebas. Jika nilai VIF kurang dari 10 dan atau nilai Tolerance lebih dari 0,01 Dengan melihat hasil ini maka diambil keputusan untuk menghilangkan variable pertumbuhan Ekonomi sehingga hasil dari matriks korelasinya adalah:

\section{Tabel 5 Hasil Coefficients ${ }^{a}$}

\begin{tabular}{|l|r|r|}
\hline \multirow{2}{*}{ Model } & \multicolumn{2}{|c|}{ Collinearity Statistics } \\
\cline { 2 - 3 } & Tolerance & \multicolumn{1}{c|}{ VIF } \\
\hline (Constant) & & \\
KEMISKINAN & .012 & 86.488 \\
KELUARGAPRASEJAHTERA & .033 & 30.225 \\
PDRBPERKEBUNAN & .055 & 18.179 \\
PDRBINDUSTRIPENGOLAHAN & .075 & 13.357 \\
HUTANLINDUNG & .013 & 75.877 \\
HUTANRAKYAT & .018 & 56.112 \\
LUASSAWAH & .121 & 8.249 \\
\hline
\end{tabular}

Sumber: Hasil Perhitungan

Maka dapat disimpulkan dengan tegas bahwa tidak terdapat masalah multikolinearitas. Dan sebaliknya maka dapat disimpulkan dengan tegas pula bahwa multikolinearitas telah terjadi dalam model. Selanjutnya yang terakhir di dalam output proses yang sudah kita lakukan, kita perhatikan nilai dari collinearity diagnostics seperti di bawah ini : hasil yang diperoleh adalah :

$$
\begin{aligned}
& \mathrm{IPM}=110.006-1.603 \mathrm{~K}+0,556 \mathrm{PraS}-.0,665 \mathrm{PDRB} \mathrm{KS}+0, .892 \text { PDRB IP }-4.120 \\
& \text { LHL - .0,017 LHR .+ 0, } 247 \text { L.saw } \\
& \text { t-stat }=\quad \begin{array}{lllllll}
0.0,877 & 0.937 & 0.705 & 0.353 & -0.962 & -0,399 & 0,951
\end{array}
\end{aligned}
$$

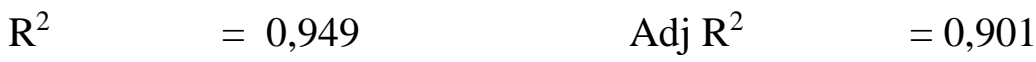

$$
\begin{aligned}
& \text { F-stat }=11,305
\end{aligned}
$$

Model estimasi di atas menginterpretasikan bahwa nilai-nilai koefisien dari perolehan hasil regresi di atas dapat diartikan sebagai berikut:

\section{Variabel Kemiskinan (K)}

Dari hasil estimasi diatas diperoleh nilai koefisien sebesar 0.913 dan bernilai negatif yang artinya, setiap penambahan kenaikan 1 persen indek pembangunan masyarkat maka kemiskinan akan turun sebesar 1,603 persen, ceteris paribus.

\section{Variabel Keluarga Pra Sejahtera (Pra S)}


Dari hasil estimasi diatas diperoleh nilai koefisien sebesar 0.556 dan bernilai negatif yang artinya, setiap penambahan kenaikan 1 persen indek pembanguna masyarakat maka kelaurga pra sejahtera akan bertambah pula sebesar $0,556 \%$, ceteris paribus.

\section{Variabel PDRB Perkebunan Kelapa Sawit (PDRB KS)}

Dari hasil estimasi diatas diperoleh nilai koefisien sebesar 0.665 dan bernilai positif yang artinya, setiap pertambahan sebanyak 1 persen indek pembangunan manusia maka PDRB perkebunan kelapa sawit akan bertambah pula sebesar 0,665\%, ceteris paribus.

\section{Variabel PDRB Industri Pengelolaan (PDRB IP)}

Dari hasil estimasi diatas diperoleh nilai koefisien sebesar 0.892 dan bernilai positif yang artinya, setiap pertambahan sebanyak 1 persen indek pembangunan manusia maka PDRB perkebunan kelapa sawit akan bertambah pula sebesar $0,892 \%$, ceteris paribus.

\section{Variabel Luas Hutan Rakyat (LHL)}

Dari hasil estimasi diatas diperoleh nilai koefisien sebesar 4.120 dan bernilai negatif yang artinya, setiap pertambahan sebanyak 1 persen indek Pembangunan manusia maka Luas Hutan Lindung akan berkurang pula sebesar 4,120 \%, ceteris paribus.

\section{Variabel Luas Hutan Rakyat (LHR)}

Dari hasil estimasi diatas diperoleh nilai koefisien sebesar 0.017 dan bernilai negatif yang artinya, setiap pertambahan sebanyak 1 persen indek Pembangunan manusia maka Luas Hutan Rakyat akan berkurang pula sebesar 0,017 \%, ceteris paribus.

7. Variabel Luas Sawah (L saw)

Dari hasil estimasi diatas diperoleh nilai koefisien sebesar 4.120 dan bernilai negatif yang artinya, setiap pertambahan sebanyak 1 persen indek Pembangunan manusia maka Luas Hutan Lindung akan berkurang pula sebesar 4,120 \%, ceteris paribus.

\section{Variabel Luas Sawah (L Saw)}

Dari hasil estimasi diatas diperoleh nilai koefisien sebesar 0.247 dan bernilai positif yang artinya, setiap pertambahan sebanyak 1 persen indek Pembangunan manusia maka Luas sawah akan bertambah pula sebesar $0,247 \%$, ceteris paribus

\section{Uji Autocorrelation}

Metode pengujian untuk mendeteksi adanya masalah atau asumsi autokorelasi, antara lain: Breusch Godfrey, Durbin Watson dan Durbin Watson H. dalam kesempatan ini, kita akan fokus untuk membahas tutorial uji autokorelasi dengan SPSS menggunakan metode Durbin Watson Test. 


\section{Tabel 6 Hasil Autocorrelation}

\begin{tabular}{|c|c|c|c|c|c|c|c|c|c|c|}
\hline \multirow[b]{2}{*}{ Model } & \multirow[b]{2}{*}{$\mathrm{R}$} & \multirow[b]{2}{*}{ R Square } & \multirow{2}{*}{$\begin{array}{l}\text { Adjusted } \\
\text { R Square }\end{array}$} & \multirow{2}{*}{$\begin{array}{l}\text { Std. Error } \\
\text { of the } \\
\text { Estimate }\end{array}$} & \multicolumn{5}{|c|}{ Change Statistics } & \multirow{2}{*}{$\begin{array}{l}\text { Durbin- } \\
\text { Watson }\end{array}$} \\
\hline & & & & & $\begin{array}{l}\text { R Square } \\
\text { Change }\end{array}$ & F Change & df1 & df2 & $\begin{array}{c}\text { Sig. F } \\
\text { Change }\end{array}$ & \\
\hline 1 & $.949^{\mathrm{a}}$ & .901 & .212 & .54371 & .901 & 1.307 & 7 & 1 & .589 & 3.291 \\
\hline
\end{tabular}

Sumber: Hasil Perhitungan

Dari hasil perhitungan diatas dapat dilihat bahwa tidak terjadi autokorelasi pada hasil estimasi IPM, karena dari hasil LM Test diperoleh nilai Prob. Chi-Square 3,291 lebih besar dari tingkat signifikansinya $(\alpha 5 \%=0,05)$.

\section{Kesesuaian (test of goodness of fit)}

Berdasarkan hasil pengolahan data yang dilakukan diperoleh nilai $\mathrm{R}^{2}$ sebesar 0,901 yang artinya bahwa delapan variable determinan IPM Kabupaten Labuhanbatu secara bersama-sama berpengaruh signifikan terhadap IPM Kabupaten Labuhanbatu sebesar 90,1\%, sedangkan sebesar 9,1\% dipengaruhi oleh variable diluar variable penelitian.

Dari hasil pengolahan data juga diperoleh nilai $\mathbf{F}$ stat sebesar 11,301 lebih besar dari $\mathrm{F}$ tabel sebesar 2.77, yang artinya bahwa secara keseluruhan variable kemiskinan, keluarga pra sejahtera, PDRB Perkebunan Kelapa sawit, PDRB Industri Pengelolaan, hutan lindung, hutan rakyat, luas sawah terhadap peningkatan IPM Kabupaten Labuhanbatu.

Hasil uji t (pastial test) mengindikasikan bahwa dari keempat determinan PDRB yang digunakan dalam penelitian ini, diperoleh hasil uji t sebagai berikut:

\section{Kemsikinan}

Variable ini memperoleh nilai t-stat sebesar 2,836 lebih kecil dari t-tabel sebesar $1.85955(\alpha=10 \%)$, artinya bahwa variable kemiskinan ini berpengaruh terhadap IPM Kabupaten Labuhanbatu yang berdasarkan kepada Pertumbuhan Ekonomi.

2. Keluarga Pra Sejahtera

Variable ini memperoleh nilai t-stat sebesar -0,388 lebih kecil dari t-tabel sebesar $1.85955(\alpha=10 \%)$, artinya bahwa keluarga pra sejahtera ini berpengaruh terhadap IPM Kabupaten Labuhanbatu yang berdasarkan kepada pertumbuhan ekonomi.

\section{PDRB Perkebunan Kelapa Sawit}

Variable ini memperoleh nilai t-stat sebesar 2,951 lebih besar dari t-tabel sebesar $1.85955(\alpha=5 \%)$, artinya bahwa PDRB Kabupaten Labuhanbatu ini berpengaruh terhadap IPM Kabupaten Labuhanbatu yang berdasarkan kepada pertumbuhan ekonomi 


\section{PDRB Industri Pengelolaan}

Variable ini memperoleh nilai t-stat sebesar -0,877 lebih kecil dari t-tabel sebesar $1.85955(\alpha=10 \%)$, artinya bahwa PDRB industri pengelolaan ini tidak berpengaruh terhadap IPM Kabupaten Labuhanbatu yang berdasarkan kepada Ppertumbuhan ekonomi.

\section{Luas Hutan Lindung}

Variable ini memperoleh nilai t-stat sebesar 0937 lebih kecil dari t-tabel sebesar $1.85955(\alpha=10 \%)$, artinya bahwa luas hutan lindung ini tidak berpengaruh terhadap IPM Kabupaten Labuhanbatu yang berdasarkan kepada pertumbuhan ekonomi.

\section{Luas Hutan Rakyat}

Variable ini memperoleh nilai t-stat sebesar 3,705 lebih besar dari t-tabel sebesar $1.85955(\alpha=10 \%)$, artinya bahwa luas hutan rakyat ini berpengaruh terhadap IPM Kabupaten Labuhanbatu yang berdasarkan kepada pertumbuhan ekonomi.

\section{Luas Sawah}

Variable ini memperoleh nilai t-stat sebesar 3,353 lebih besar dari t-tabel sebesar $1.85955(\alpha=10 \%)$, artinya bahwa luas sawah ini berpengaruh terhadap IPM Kabupaten Labuhanbatu yang berdasarkan kepada pertumbuhan ekonomi

\section{Kesimpulan}

Berdasarkan hasil analisis data yang dilakukan, maka dapat disimpulkan beberapa hal sebagai berikut :

1. Secara umum, variabel pertumbuhan ekonomi kabupaten Labuhanbatu selama periode tahun 2010-2019 mengalami fluatuasi mengikuti keadaan yang terjadi di Indonesia. Pertumbuhan eKonomi di mulai pada tahun 2010 disebabkan pada tahun 2008 Kabupaten Labuhanbatu di mekarkan menjadi 3 Kabupaten sehingga data sepenuh Kabupaten di mulai tahun 2010 Kondisi IPM Kabupaten Labuhanbatu cenderung mengalami peningkatan setiap tahunnya dengan rata-rata IPM semakin tinggi selama periode 2010-2019. Berdasarkan hasil uji kointegrasi menunjukkan bahwa terdapat dampak ekonomi dari peningkatan perkebunan kelapa sawit terhadap tingkat kesejateraan masyarakat dengan melihat data IPM Kabupaten Labuhanbatu dengan melalui pertumbuhan ekonomi.

2. Kegiatan pembangunan perkebunan telah menimbulkan mobilitas penduduk yang tinggi. Akibatnya di daerah-daerah sekitar pembangunan perkebunan muncul pusatpusat pertumbuhan ekonomi di pedesaan. Kondisi ini menyebabkan meningkatnya daya beli masyarakat pedesaan, terutama terhadap kebutuhan rutin rumah tangga dan 
kebutuhan sarana produksi perkebunan kelapa sawit. Perputaran uang yang terjadi di lokasi dalam jangka panjang diperkirakan dapat merangsang pertumbuhan ekonomi di wilayah ini dengan tumbuhnya perdagangan dan jasa. Hal ini memberikan arti bahwa kegiatan perkebunan kelapa sawit di pedesaan menciptakan multiplier effect, terutama dalam lapangan pekerjaan dan peluang berusaha.

\section{Daftar Pustaka}

Adi, Isbandi Rukminto. 2013, Kesejahteraan sosial (Pekerjaan sosial, Pembangunan Sosial, dan Kajian Pembangunan),Jakarta: PT. Raja Grafindo Persada.

Almasdi (2014) Percepatan Ekonomi Pedesaan Melalui Pembagunan Perkebunan Kelapa Sawit, Jurnal Ekonomi Pembangunan Volume 12, Nomor 2, Desember 2011, hlm.297310

Badan Pusat Statistik. Badan Pusat Statistik Propinsi Sumatera Utara, 2011. Medan

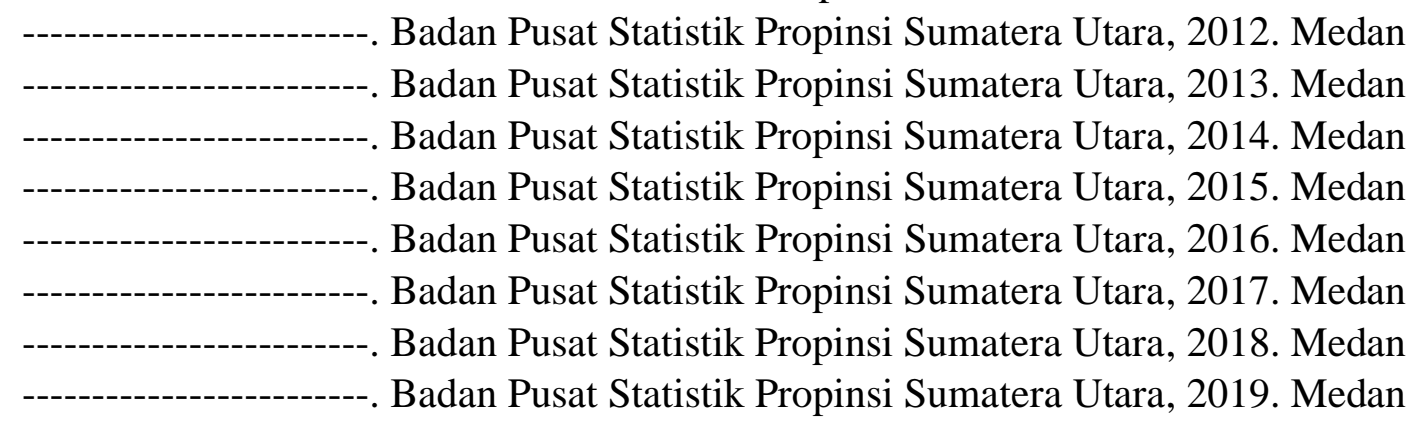

Hainim Kadir dan Syapsan (2012) Peranan Perkebunan Kelapa Sawit Dalam Memyerap Tenaga Kerja Di Kabupaten Rokan Hulu, Jurnal Sosial Ekonomi Pembangunan Tahun III No. 7, November $2012: 24-32$

Hartanto H. 2011. Sukses Besar Budidaya Kelapa Sawit. Cetakan I.Yogyakarta:Citra Media Publishing

Supardi dan A. R. Nurmanaf. 2006. Pendapatan dan Pengeluaran Rumah Tangga Pedesaan dan Kaitannya dengan Tingkat Kemiskinan. Jurnal Socio-Economic of Agriculturre and AgribusinessVolume 6, No3 November 2006

Pardamean, M. 2016. Mengelola Kebun dan Pabrik Kelapa Sawit secara Profesional. Penebar Swadaya. Jakarta.

Rambe, A., 2004. Alokasi Pengeluaran Rumah Tangga dan Tingkat Kesejahteraan (Kasus di Kecamatan Medan Kota, Sumatera Utara). Tesis. Sekolah Pascasarjana IPB. Bogor.

Scoot, James C. 1976. Moral Ekonomi Petani. Jakarta: LP3S

UNDANG-UNDANG REPUBLIK INDONESIA NOMOR 18 TAHUN 2004 TENTANG PERKEBUNAN

Whithaker, William H. and Ronald C. Frederico, 1997. Social welfare in Today's World, Second Edition. New York: the McGraw-Hill Companies.

Zulkarnain Nasution, (2011) Analisis Determinan Pertumbuhan Eekonomi Kabupaten Labuhanbatu, Tesis Program Studi Ekonomi Pembangunan pada Sekolah Pascasarjana Universitas Sumatera Utara 